\title{
PERCOBAAN EKONOMI UNTUK MENGKAJI PENGARUH INFORMASI SERTA JUMLAH PENJUAL DAN PEMBELI DALAM TRANSAKSI PASAR
}

\author{
Edy Supriyadi \\ Universitas Pancasila, Jln. Srengseng Sawah Jagakarsa, Jakarta Selatan 12640
}

\begin{abstract}
Perfect competition (PPS) is the most ideal market structure because this market system is considered will ensure the realization of activities producing goods and services with very high efficiency compared to other market structures such as monopoly. Due to its benefits for sellers and buyers, economists often wish for the creation of perfect competition. In the pattern of transactions in everyday life, there are many market transactions commonly encountered, such as decentralized systems (DT), and Double Auction (DA). This paper presents the use of experimental methods to study the characteristics of both systems the transaction is in a "perfect competition" (5 sellers and 5 buyers' and market monopoly (with 1 seller and 5 buyers). Responses observed are Contract Price (CP), market efficiency, CP diversity coefficient on the price balance, buyer surplus and seller surplus. From the experimental results can be seen that the average Contract Price (CP) during 5 experimental periods that the value of CP at Perfect Competition Market is smaller than the monopoly market. From efficiency levels between transactions type it can be seen that the Double Auction type of transaction is more efficient than with the Decentralization type of transaction.
\end{abstract}

Keywords: economic experiment, information influence, market transaction

\begin{abstract}
ABSTRAK
Pasar persaingan sempurna (PPS) merupakan struktur pasar yang paling ideal karena dianggap sistem pasar ini akan menjamin terwujudnya kegiatan memproduksi harang-barang dan jasa-jasa yang sangat tinggi efisiensinya dibandingkan dengan struktur pasar yang lain seperti monopoli. Karena sifatnya menguntungkan bagi penjual dan pembeli, seringkali para ekonom mengharapkan terciptanya pasar persaingan sempurna. Pola transaksi dalam kehidupan sehari dan, ada berbagai transaksi pasar yang biasa ditemui. diantaranya adalah sistem desentralisasi (DT), Double Auction (DA). Makalah ini menyajikan penggunaan metode percobaan untuk mengkaji karakteristik kedua sistem transaksi tersebut dalam "pasar persaingan sempurna (5 penjual dan 5 pembeli” dan pasar monopoli (dengan 1 penjual dan 5 pembeli). Respon yang diamati yaitu Contract Price $(C P)$, efisiensi pasar, koefisien keragaman CP terhadap harga keseimbangan, surplus pembeli dan surplus penjual. Dari hasil percobaan dapat dilihat bahwa rata-rata Contract Price (CP) selama 5 periode percobaan terdapat bahwa nilai CP pada Pasar Persaingan Sempurna lebih kecil dibandingkan dengan Pasar monopoli. Tingkat Efisiensi antar tipe transaksi terlihat bahwa tipe transaksi Double Auction lebih efisien dibandingkan dengan tipe transaksi Desentralisasi.
\end{abstract}

Kata kunci: percobaan ekonomi, pengaruh informasi, transaksi pasar 


\section{PENDAHULUAN}

Pasar Persaingan Sempurna (PPS) merupakan struktur pasar yang paling ideal karena dianggap sistem pasar ini akan menjamin terwujudnya kegiatan memproduksi harang-barang dan jasajasa yang sangat tinggi efisiensinya dibandingkan dengan struktur pasar yang lain seperti monopoli. Karena sifatnya menguntungkan bagi penjual dan pembeli, seringkali para ekonom mengharapkan terciptanya pasar persaingan sempurna. Namun, dalam beberapa buku teks ekonomi, dinyatakan bahwa syarat-syarat yang harus dipenuhi bagi terbentuknya pasar persaingan sempurna adala jumlah pembeli dan jumlah penjual banyak; adanya kebebasan bagi pelaku ekonomi keluar-masuk pasar; produk yang dipasarkan homogen; dan informasi yang sempurna, artinya para pembeli dan penjual mengetahui tentang keadaan pasar yaitu tingkat harga yang berlaku dan perubahan-perubahan hargaharga tersebut.

Pasar monopoli merupakan struktur pasar, di mana terdapat hanya seorang penjual atau produsen dengan banyak pembeli. Adapun sifat-sifat pasar monopoli adalah jumlah penjual hanya satu dengan banyak pembeli, kecenderung harga ditentukan oleh penjual saja, pembeli hanya berlaku sebagai price-taker, dan produk yang dipasarkan hanya satu macam. Masalahnya di sini adalah apakah untuk mewujudkan kondisi pasar persaingan sempurna harus memenuhi keempat syarat di atas, atau mungkin ada suatu syarat yang jika dipenuhi sudah cukup memenuhi karakteristik pasar persaingan sempurna (sufficient condition). Pola transaksi dalam kehidupan sehari dan ada berbagai transaksi pasar yang biasa ditemui, di antaranya adalah sistem desentralisasi (DT), double auction (DA). Transaksi pasar yang sering ditemui adalah sistem desentralisasi. Dalam sistem mi pembeli dan penjual bebas dan aktif mencari pasangannya untuk melakukan tawar menawar harga atas suatu barang dagangan. Sistem transaksi ini agak tertutup karena semua informasi tentang penawaran penjual (offers), permintaan pembeli (bids) dan harga yang disepakati (Contract Price) tidak diketahui oleh semua pelaku pasar atau publik.

Sedangkan sistem double auction merupakan sistem pelelangan 2 arah, yaitu semua penjual dan pembeli sama-sama melakukan tawar menawar harga terhadap suatu barang sehingga semua informasi diketahui oleh publik atau semua penjual dan pembeli dalam pelelangan tersebut.

Penelitian ini menyajikan penggunaan metode percobaan untuk mengkaji karakteristik kedua sistem transaksi tersebut dalam "pasar persaingan sempurna" (5 penjual dan 5 pembeli dan pasar monopoli, dengan 1 penjual dan 5 pembeli). Respon yang diamati, yaitu Contract Price (CP), efisiensi pasar, koefisien keragaman CP terhadap harga keseimbangan, surplus pembeli, dan surplus penjual. Keterangan mengenai respon dan cara menghitungnya dapat dilihat dalam Lampiran.

Pokok permasalahan dalam penelitian ini adalah sebagai berikut (1) Bagaimana performance tipe pasar (PPS dan MO) dengan tipe transaksi (DT dan DA) dengan nilai ukur Contract Price, efisiensi, surplus konsumen, surplus produsen, dan variance; (2) Apakah terdapat perbedaan rata-rata Contract Price antara tipe pasar (PPS dan MO) serta antara tipe transaksi (DT dan DA); (3) Apakah terdapat interaksi antara tipe pasar dengan tipe transaksi.

Percobaan ekonomi versus survei adalah sebagai berikut. Dalam beberapa hal, untuk menyelidiki hubungan sebab akibat sering tidak dapat dilakukan dengan cara survei atau pengamatan langsung. Sebagai ilustrasi, penulis sajikan cerita sindiran antara Monetris dan Keynessian yang ditulis oleh Edward Leamer, penulis buku Study Econometrics, yang pernah menulis artikel "Let's take the Con of Econometrics” pada Jurnal American Economic Review yang sempat menggegerkan para pakar ekonometrika. Dalam artikel tersebut, Leamer menyindir Monetrais dan Keynessian menggunakan cerita perumpamaan yang menarik tentang 'Kaum Luminish (Ahli Cahaya) Vs Kaum Aviophile (Ahli Perburungan)'. 
Dalam cerita Leamer "Kaum Luminist dan kaum pecinta burung terlibat pada perdebatan tentang hasil suatu tanaman yang tumbuh di bawah pohon yang sering dihinggapi oleh burung. Kaum Luminist percaya bahwa hasil pohon yang tinggi tersebut disebabkan karena pohon menerima intensitas cahaya yang baik karena ada pohon rindang di atasnya. Sementara itu, kaum pecinta burung percaya bahwa hasil tanaman yang tinggi tersebut disebabkan oleh burung yang hinggap di atas pohon tersebut, kemudian membuang kotorannya sehingga menyuburkan tanah dan akhirnya tanaman tersebut hasilnya lebih baik dibandingkan tanaman yang lainnya.

Jika kita tertarik untuk membuktikan apakah kaum Luminist yang benar atau kaum pecinta burung yang benar atau kedua-duanya benar atau malahan kedua-duanya salah (karena bisa jadi hasil tanaman yang lebih baik, bukan disebabkan oleh tumbuhan yang bisa memberikan intensitas cahaya yang baik dan kotoran burung, tetapi karena faktor lain), maka kita harus punya bukti, fakta, atau data. Pembuktian dengan teori pun tidak berhasil menyimpulkan siapa yang benar dan siapa yang salah karena teori yang dipahami saat itu adalah "kalau tanaman diberi pupuk kotoran burung tanaman tersebut akan subur" dan "kalau tanaman tersebut diberikan intensitas cahaya yang baik, maka tanaman juga akan subur”.

Pertanyaannya adalah mungkinkah bukti atau fakta atau data tersebut dapat diperoleh dengan cara survei atau mengobservasi?. Teknik survei apakah memungkinkan kita untuk memperoleh bukti bahwa kaum Luminist atau kaum Aviophile yang benar atau kedua-duanya benar?. Jika kita dapat memperoleh amatan ada tanaman di bawah pohon tanpa ada burung yang hinggap dan kita amati hasilnya serta memperoleh amatan tanaman yang hanya diberi kotoran burung serta amatan tanaman yang ada pohonnya dan dihinggapi burung yang mengeluarkan kotorannya. Untuk memperoleh amatan keadaan yang demikian sungguh sangat sulit apalagi kalau disyaratkan tanahnya harus sama, iklimnya sama dan faktor-faktor lainnya dianggap sama. Usaha tersebut akan mendekati kemustahilan, bukan?. Dengan merancang percobaan, bukti atau fakta atau data tersebut dapat digali. Oleh karena itu, perancangan percobaan menjadi alternatif dalam membangkitkan data atau fakta. Percobaan yang dimaksud adalah kita membuat model tiruan untuk fenomena di atas di dalam laboratorium dengan beberapa modifikasi.

Pertama, kita membuat keadaan yang mirip dengan keadaan di atas laboratorium, yaitu membuat satuan percobaan dengan menanam tanaman, kemudian di sampingnya kita berikan (tanaman) pohon yang besar yang dapat menyaring intensitas cahaya, tetapi kita isolasikan sehingga burung tidak bisa hinggap pada pohon yang besar tersebut. Kedua, kita membuat satuan percobaan dengan tanaman tanpa pohon yang besar tersebut, kemudian tanaman tersebut kita pupuk dengan kotoran burung yang sering menghinggapi pohon yang besar tadi. Karena percobaan ini dilakukan di laboratorium, maka faktor-faktor lain antar satuan percobaan dianggap sama, yaitu kesuburuan tanahnya sama, pemberian irigasinya sama, pestisidanya juga sama, dan faktor iklim juga sama.

Ketiga, kita membuat satuan percobaan sebagai kontrol, yaitu menanam tanaman tanpa ada pohon dan tanpa kotoran burung. Dalam hal ini, kita telah melakukan percobaan untuk membuktikan apakah hasil tanaman yang lebih baik disebabkan oleh karena pohon yang ada di sebelah tanaman atau karena kotoran burung yang hinggap di atas pohon tersebut. Jika hasil tanaman pada satuan percobaan pertama lebih baik daripada satuan percobaan kedua dan ketiga, sementara hasil satuan percobaan kedua dan ketiga tidak berbeda nyata, maka kita akan cenderung menyimpulkan bahwa hasil tanaman yang lebih baik disebabkan karena ada pohon yang dapat mengatur intensitas cahaya. Dalam hal ini, kita cenderung menerima pendapat kaum Luminist. Tetapi, jika hasil satuan percobaan kedua lebih tinggi daripada satuan percobaan pertama dan ketiga, sementara satuan percobaan pertama hasilnya sama dengan satuan percobaan ketiga, maka kita akan cenderung menerima pendapat kaum pecinta burung, yaitu bahwa hasil tanaman yang lebih baik disebabkan karena kotoran burung yang hinggap di atas pohon tersebut. 
Sampai di sini kita telah menguji dugaan kaum Luminist dan kaum pecinta burung dengan melakukan percobaan. Tetapi, apakah dengan satu satuan percobaan (satu data) tersebut kita sudah yakin dengan kesimpulan tersebut?. Berapa tingkat keyakinan kita untuk menerima atau menolak pendapat kaum Luminist atau kaum pecinta burung?. Oleh karena itulah, agar percobaan kita dapat diukur tingkat keyakinannya dan dapat dievalusai dengan peluang, maka percobaan tersebut memerlukan ulangan (replication) dan dilakukan dengan proses pengacakan.

Tabel 1 Perbedaan Metode Survei dan Metode Percobaan

\begin{tabular}{lll}
\hline \multicolumn{1}{c}{ Metode Survei } & \multicolumn{1}{c}{ Metode Percobaan } \\
\hline - $\begin{array}{l}\text { Peneliti tidak memiliki kendali dalam pengumpulan } \\
\text { data, kecuali dalam menentukan faktor yang } \\
\text { diamati dan memeriksa ketelitiannya }\end{array}$ & $\begin{array}{l}\text { Peneliti memiliki keleluasaan untuk melakukan } \\
\text { pengawasan terhadap sumber-sumber keragaman } \\
\text { data }\end{array}$ \\
- $\begin{array}{l}\text { Perubahan yang terjadi pada respons sulit diketahui } \\
\text { penyebabnya, karena mungkin disebabkan oleh } \\
\text { faktor yang tidak diamati atau bahkan sebenarnya } \\
\text { belum diketahui oleh penelitinya, sehingga tidak } \\
\text { kuat untuk menerangkan hubungan sebab akibat }\end{array}$ & $\bullet \begin{array}{l}\text { Dapat menciptakan jenis perlakuan yang } \\
\text { diinginkan kemudian mengamati perubahan- } \\
\text { perubahan yang terjadi pada responnya }\end{array}$ \\
$\begin{array}{l}\text { Telaahnya biasanya bersifat enumeratif yaitu } \\
\text { bertujuan untuk menduga nilai agregat populasi }\end{array}$ & $\begin{array}{l}\text { Jadi telaahannya dapat bersifat analitik, yang } \\
\text { bertujuan untuk menjelaskan hubungan sebab } \\
\text { akibat antar berbagai faktor }\end{array}$ \\
\hline
\end{tabular}

Untuk menjelaskan kelebihan dan kekurangan dari antara percobaan dengan survei dapat diberikan ilustrasi sebagai berikut: "Misalkan saja kita ingin melihat apakah ada perbedaan efektivitas antara 2 jenis Pengobatan A dan B”. Dengan metode percobaan, pasien-pasien yang memenuhi syarat dikelompokkan menjadi 2 grup yang berbeda dengan prosedur pengacakan sehingga masing-masing pasien mendapat kesempatan yang sama untuk menerima salah satu jenis pengobatan. Selanjutnya, diusahakan agar supaya lingkungan maupun perawatan yang diterima setiap pasien relatif seragam, kecuali jenis pengobatan yang dijadikan sebagai treatment. Apabila kemudian ditemukan ada perbedaan waktu kesembuhannya (dengan analisis yang sesuai), maka terdapat alasan untuk meyimpulkan kesembuhannya dipengaruhi oleh cara pengobatannya. Dengan metode survei (observasi), kita hanya mengamati sejumlah pasien yang diberi atau mengakui menerima pengobatan jenis tertentu tanpa usaha-usaha pengawasan selanjutnya. Seandainya terdapat perbedaan dalam waktu kesembuhannya, agak sulit untuk menyimpulkan apakah hal ini benar-benar disebabkan oleh perbedaan jenis pengobatan karena mungkin banyak faktor lain yang ikut berperan dalam proses penyembuhan karena dalam metode ini tidak diperhatikan dengan baik.

Dibandingkan dengan metode survei, pengumpulan data dengan metode percobaan ekonomi mempunyai beberapa kelebihan, di antaranya (1) Peneliti mempunyai keleluasaan untuk melakukan pengawasan terhadap lingkungan atau sumber-sumber keragaman data (control), (2) Dapat menciptakan jenis perlakuan yang diinginkan, kemudian mengamati perubahan-perubahan yang terjadi pada responnya, (3) Telaahannya bersifat analitik, yang bertujuan untuk menjelaskan hubungan sebab akibat berbagai faktor, (4) Replicibility, yaitu kemudahan untuk ditiru. Hal ini menunjukkan bahwa peneliti lain dapat melakukan kembali percobaan yang sama dan dengan cara yang sama pula dapat menguji temuan-temuan atau kesimpulan yang telah ada.

Bagaimana percobaan ekonomi dilakukan dapat dijelaskan sebagai berikut. Dari kuliah-kuliah ekonomi mikro, kita menyadari bahwa sistem ekonomi mikro merupakan suatu landasan pemahaman kosep ekonomi yang lengkap, sederhana, namun juga memadai untuk memahami fenomena ekonomi dunia nyata yang sangat kompleks. Di dalam dunia nyata yang kompleks tersebut, ilmu ekonomi mikro menemukan sekelompok para agen ekonomi (produsen, pedagang, dan konsumen) beserta institusi-institusinya (sistem aturan pertukaran barang dan jasa, di mana melalui institusi ini para agen 
berinteraksi, yaitu para pembeli, pedagang (penjual), dan produsen beroperasi dalam kedaan pasar tertentu. Percobaan ekonomi dapat dilaksanakan dengan meniru fenomena ekonomi tersebut dengan merekayasa suatu percobaan, yang terdiri dari para agen dan institusinya serta sistem reward yang dapat memunculkan (meng-induced) karakteristik pelaku ekonomi tertentu sehingga karakteristik bawaannya menjadi tidak relevan. Percobaan ekonomi memerlukan seni dan ilmu rekayasa tersendiri agar fenomena ekonomi tersebut dapat ditelaah seperti keadaan dunia nyata (riil).

Induced value theory digunakan untuk memunculkan karakteristik pelaku ekonomi tertentu sehingga karakteristik bawaannya menjadi tidak relevan. Prinsip induce value theory yang digunakan adalah (1) Monotonicity, yaitu mempengaruhi subjek penelitian agar lebih menyukai imbalan yang terbesar dan tidak pernah merasa puas akan imbalan yang mereka peroleh. Kondisi ini dapat dengan mudah dipenuhi dengan cara memberikan imbalan dalam bentuk uang; (2) Salience, yaitu memberikan imbalan kepada subjek penelitian tergantung kepada tindakan mereka (serta pelaku lain) yang sesuai dengan peraturan yang ada (aturan mainnya direkayasa sedemikian rupa imbalan tergantung pada tindakan subjek penelitian); (3) Dominance, yaitu adanya dominasi kepentingan subjek penelitian di dalam percobaan, di mana mereka lebih mengutamakan imbalan dan mengabaikan hal-hal lainnya.

Friedman dan Sunder (1994) mengemukakan bahwa percobaan ekonomi dilakukan di dalam lingkungan yang terkontrol sehingga jika terjadi perbedaan respon memang karena disebabkan oleh perbedaan perlakukan (treatment), bukan dari sebab yang lainnya. Lingkungan ekonomi yang dimaksud terdiri dari pelaku-pelaku ekonomi beserta aturan-aturan atau institusi sebagai tempat berinteraksi antar pelaku ekonomi. Pelaku ekonomi mungkin sebagai pembeli dan penjual, dan institusinya mungkin merupakan tipe pasar tertentu. Contoh lain dalam bidang politik, misalnya pemilih sebagai pelaku dan aturan mayoritas sebagai suatu intitusi.

\section{METODE PENELITIAN}

Bahan yang digunakan adalah produk jeruk, yang terdiri jeruk I dan jeruk II, di mana harga jeruk I lebih murah dengan harga jeruk II. Sebagai percobaan, dipergunakan dalam penelitian ini adalah data hasil percobaan ekonomi dengan melibatkan 32 orang mahasiswa sebagai pelaku percobaan (experimental unit), yang dibagi dalam 4 kelompok percobaan ekonomi (kombinasi perlakuan). Pertama, sebanyak 10 orang dipilih secara 'acak' siapa yang menjadi penjual (5 orang) dan siapa yang menjadi pembeli (5 orang), kemudian mereka melakukan simulasi percobaan elconomi dengan aturan sistem 'desentialisasi' sebanyak 5 kali (periode). Perlakuan ini dinotasikan sebagai PPSDT. Kedua, sebanyak 10 orang dipilih secara 'acak' siapa yang menjadi pembeli (5 orang) dan siapa yang menjadi pembeli (5 orang), kemudian mereka melakukan simulasi percobaan ekonomi dengan aturan sistem double auction sebanyak 5 kali (periode). Perlakuan ini dinotasikan sebagai PPS-DA. Ketiga, sebanyak 6 orang dipilih secara acak' siapa yang menjadi penjual (1 orang) dan siapa yang menjadi pembeli (5 orang), kemudian mereka melakukan simulasi percobaan ekonomi dengan aturan sistem 'desentralisasi' sebanyak 5 kali (periode). Perlakuan ini dinotasikan sebagai MO-DT. Keempat, sebanyak 6 orang dipilih secara 'acak' siapa yang menjadi penjual (1 orang) dan siapa yang menjadi pembeli (5 orang), kemudian mereka melakukan simulasi percobaan ekonomi dengan aturan sistem double auction sebanyak 5 kali (periode). Perlakuan mi dinotasikan sebagai MO-DA.

Dari gambaran perancangan percobaan di atas, dapat dinyatakan bahwa faktor-faktor yang akan dilihat pengaruhnya terhadap respon percobaan adalah (1) Jumlah penjual yang terdiri atas 2 taraf, yaitu 5 orang penjual (PPS dan 5 orang penjual (MO); (2) Sistem transaksi yang terdiri atas taraf, yaitu desentralisasi (DT) dan Double Auction (DA). 
Masing-masing penjual dari tiap kelompok percobaan ekonomi di atas diberikan unit cost untuk barang yang akan dijualnya. Demikian juga, masing-masing pembeli dari tiap kelompok percobaan ekonomi di atas diberikan unit value untuk barang yang akan dibelinya. Kumpulan nilai unit cost yang dipegang oleh para penjual di tiap kelompok percobaan akan membentuk suatu kurva penawaran teroritis, dan kumpulan nilai unit value yang dipegang oleh para pembeli di tiap kelompok percobaan akan membentuk suatu kurva permintaan teroritis. Kedua kurva teoritis ini dapat dilihat pada Gambar 1. Jika kondisi pasar persaingan sempurna, maka respon Harga Keseimbangan Teoritis (HKT) akan dicapai pada harga Rp 550, dan jumlah transaksi (Q) sebanyak 7 atau 8 barang. Dalam percobaan ini, akan dikaji bagaimana repon atau karateristik dari 6 kelompok percobaan (kombinasi perlakuan) tersebut.

\section{Jalannnya Percobaan}

Percobaan yang dilakukan oleh Kelompok Mahasiswa S3 jurusan PWD tahun 2003/2004 telah dilaksanakan pada tanggal 6 April 2004, bertempat di Fakultas Ekonomi, Universitas Ibnu Khaldun sesuai dengan instruksi percobaan dalam lampiran 1 dan Lampiran 2. Subjek penelitian menggunakan 32 responden sebagai pelaku percobaan.

Pelaksanaan percobaan adalah sebagai berikut. Pertama, percobaan untuk pasar persaingan sempurna dan double auction, yaitu (1) Peserta yang terdiri dari 5 penjual dan 5 pembeli setelah menempati tempat duduknya masing-masing di dalam ruangan kelas (penjual dan pembeli dalam ruangan yang sama), dipersilahkan membaca dan memahami lembar instruksi percobaan yang diberikan oleh peneliti, masing-masing pembeli dan penjual diberi nomor identitas; (2) Peneliti atau yang membantu penelitian menjelaskan instruksi percobaan kepada peserta, hal-hal yang tidak dimengerti oleh peserta harus ditanyakan langsung kepada peneliti atau yang membantu penelitian; (3) Penjual mengisi unit cost dan pembeli mengisi unit value sesuai jenis barang yang akan ditawarkan. Dalam hal ini adalah 2 buah jeruk (Jeruk I dan Jeruk II) pada lampiran yang telah disediakan dengan dibantu oleh peneliti, dengan dipandu oleh peneliti; (4) Penjual dipersilahkan membuka percobaan dengan cara mengisi besar harga tawaran pada lembar keputusan penjual (Lampiran 1), begitu juga pembeli; (5) Penjual pertama dipersilahkan untuk menawarkan harga barang yang sedang ditawarkan (barang I atau II) sesuai dengan aturan percobaan; (6) Proses transaksi dimulai, para pembeli dipersilahkan untuk membeli sebuah unit barang (apabila ia ingin membeli unit barang), dengan cara mengangkat tangan dan menyebutkan harga penawaran yang diinginkan. Dalam hal ini, pembeli yang mengangkat tangan terlebih dahulu mendapat kesempatan, selanjutnya pembeli berikutnya hingga transaksi terjadi atau sampai pada pembeli terakhir; (7) Jika tidak terjadi transaksi, maka dilanjutkan dengan penawaran penjual kedua dan seterusnya hingga penjual kelima lalu kembali ke langkah 6; (8) Setiap terjadi transaksi harga, maka pembeli dan penjual harus menulis pada lampiran harga transaski tersebut; (9) Terakhir, penjual dan pembeli dipersilahkan menghitung pendapatannya masing-masing dalam periode tersebut, yaitu dengan mengisi/menghitung besar keuntungan yang diperoleh pada setiap transaksi.

Kedua, percobaan untuk pasar persaingan sempurna dan disentralisasi, yaitu (1) Peserta yang terdiri dari 5 penjual dan 5 pembeli setelah menempati tempat duduknya masing-masing di dalam ruangan kelas (penjual dan pembeli dalam ruangan yang terpisah atau ada pembatas antara kelompok pembeli dan kelompokn penjual), dipersilahkan membaca dan memahami lembar instruksi percobaan yang diberikan oleh peneliti. Masing-masing pembeli dan penjual diberi nomor identitas; (2) Peneliti atau yang membantu penelitian menjelaskan instruksi percobaan kepada peserta. Hal-hal yang tidak dimengerti oleh peserta harus ditanyakan langsung kepada peneliti atau yang membantu penelitian; (3) Penjual mengisi unit cost dan pembeli mengisi unit value sesuai jenis barang yang akan ditawarkan. Dalam hal ini adalah 2 buah jeruk (Jeruk I dan Jeruk II) pada lampiran yang telah disediakan, dengan dibantu dan dipandu oleh peneliti; (4) Penjual dipersilahkan membuka percobaan dengan cara mengisi besar harga tawaran pada lembar keputusan penjual (Lampiran 1), begitu juga pembeli; (5) Penjual 
pertama atau penjual dan dipersilahkan untuk menawarkan harga barang yang sedang ditawarkan (barang I atau II ) sesuai dengan aturan percobaan; dan (6) Proses transaksi dimulai dengan penjual pertama atau penjual-n/berikutnya mendatangi para pembeli dengan menawarkan barang (I atau II tergantung proses percobaan) dimulai dengan pembeli I. Selanjutnya akan terjadi tawar menawar harga barang. Jika terjadi transaksi, maka proses percobaan yang sedang dijalankan selesai. Tetapi, jika tidak terjadi transaksi, maka pembeli I akan mendatangi pembeli ke II dan proses berlanjut hingga pembeli kelima; (7) Selanjutnya, penjual dan pembeli menyalin harga transaksi jika terjadi transaksi pada lembar lampiran yang disediakan; (8) Selanjutnya, dilanjutkan dengan penjual kedua atau penjual ke-(n+1) dengan proses sesuai dengan langkah 5, dilakukan sampai pada penjual kelima atau penjual terakhir dengan 2 barang, dalam hal ini jeruk I dan II dengan 5 kali / periode percobaan; (9) Terakhir, penjual dan pembeli dipersilahkan menghitung pendapatannya masing-masing dalam periode tersebut, yaitu dengan mengisi/menghitung besar keuntungan yang diperoleh pada setiap transaksi.

Ketiga, percobaan untuk pasar monopoli dan double auction, yaitu (1) Peserta yang terdiri dari 1 penjual dan 5 pembeli setelah menempati tempat duduknya masing-masing di dalam ruangan kelas (penjual dan pembeli dalam ruangan yang sama), dipersilahkan membaca dan memahami lembar instruksi percobaan yang diberikan oleh peneliti, masing-masing pembeli dan penjual diberi nomor identitas; (2) Peneliti atau yang membantu penelitian menjelaskan instruksi percobaan kepada peserta. Hal-hal yang tidak dimengerti oleh peserta harus ditanyakan langsung kepada peneliti atau yang membantu penelitian; (3) Penjual mengisi unit cost dan pembeli mengisi unit value sesuai jenis barang yang akan ditawarkan, dalam hal ini adalah 2 buah jeruk (Jeruk I dan Jeruk II) pada lampiran yang telah disediakan, dengan dibantu dan dipandu oleh peneliti; (4) Penjual dipersilahkan membuka percobaan dengan cara mengisi besar harga tawaran pada lembar keputusan penjual (Lampiran 1), begitu juga pembeli; (5) Penjual dipersilahkan untuk menawarkan harga barang yang sedang ditawarkan (barang I atau II ) sesuai dengan aturan percobaan; (6) Proses transaksi dimulai, para pembeli dipersilahkan untuk membeli sebuah unit barang (apabila ia ingin membeli unit barang), dengan cara mengangkat tangan dan menyebutkan harga penawaran yang diinginkan, dalam hal ini pembeli yang mengangkat tangan terlebih dahulu mendapat kesempatan, dan selanjutnya pembeli berikutnya hingga transaksi terjadi atau sampai pada pembeli terakhir; (7) Jika tidak terjadi transaksi, maka dilanjutkan dengan penawaran barang berikutnya (barang II ) atau periode berikutnya (hingga periode kelima), lalu kembali ke langkah 6; (8) Setiap terjadi transaksi harga, maka pembeli dan penjual harus menulis pada lampiran harga transaksi tersebut; dan (9) Terakhir, penjual dan pembeli dipersilahkan menghitung pendapatannya masing-masing dalam periode tersebut, yaitu dengan mengisi/menghitung besar keuntungan yang diperoleh pada setiap transaksi.

Keempat, percobaan untuk pasar monopoli dan disentralisasi, yaitu (1) Peserta yang terdiri dari 1 penjual dan 5 pembeli setelah menempati tempat duduknya masing-masing di dalam ruangan kelas (penjual dan pembeli dalam ruangan yang terpisah atau ada pembatas antara kelompok pembeli dan penjual), dipersilahkan membaca dan memahami lembar instruksi percobaan yang diberikan oleh peneliti, masing-masing pembeli dan penjual diberi nomor identitas; (2) Peneliti atau yang membantu penelitian menjelaskan instruksi percobaan kepada peserta, hal-hal yang tidak dimengerti oleh peserta harus ditanyakan langsung kepada peneliti atau yang membantu penelitian; (3) Penjual mengisi unit cost dan pembeli mengisi unit value sesuai jenis barang yang akan ditawarkan, dalam hal ini adalah 2 buah jeruk (Jeruk I dan Jeruk II) pada lampiran yang telah disediakan, dengan dibantu dan dipandu oleh peneliti; (4) Penjual dipersilahkan membuka percobaan dengan cara mengisi besar harga tawaran pada lembar keputusan penjual (Lampiran 1), begitu juga pembeli; (5) Penjual dipersilahkan untuk menawarkan harga barang yang sedang ditawarkan (barang I atau II ) sesuai dengan aturan percobaan; (6) Proses transaksi dimulai dengan penjual mendatangi para pembeli dengan menawarkan barang (I atau II tergantung proses percobaan) dimulai dengan pembeli I, selanjutnya akan terjadi tawar menawar harga barang. Jika terjadi transaksi, maka proses percobaan yang sedang dijalankan selesai. Tetapi, jika tidak terjadi transaksi, maka penjual akan mendatangi pembeli ke II dan proses berlanjut hingga pembeli-5; (7) Selanjutnya, penjual dan pembeli menyalin harga transaksi jika terjadi transaksi pada lembar lampiran yang disediakan; (8) Selanjutnya, dilanjutkan dengan penjual dengan proses 
sesuai dengan langkah 5, barang berikutnya dengan periode percobaan atau 5 periode; (9) Terakhir, penjual dan pembeli dipersilahkan menghitung pendapatannya masing-masing dalam periode tersebut, yaitu dengan mengisi/menghitung besar keuntungan yang diperoleh pada setiap transaksi; (10) Selanjutnya, pada lembar keputusan pembeli dan penjual juga ditambahkan pertanyaan untuk mengevaluasi pertimbangan yang digunakan peserta dalam melakukan transakasi. Penggunaan uang sebagai imbalan akan dibayarkan berdasarkan total pendapatan yang diperoleh pada setiap periode yang akan dibayarkan setelah percobaan berakhir.

\section{Konsep dan Definisi}

Beberapa konsep dan definisi untuk mengukur performance pasar adalah (1) Unit value, yaitu nilai suatu barang terbagi menjadi dua, yaitu unit value penjual dan unit value pembeli; (2) Contract Price, yaitu harga yang disepakati oleh penjual dan pembeli di pasar simulasi; (3) Total Surplus Penjual (TSS) merupakan total dari kelebihan penerimaan penjual, yang di sebelah bahwa dibatasi oleh kurva penewaran dan di sebelah atas dibatasi oleh Contract Price. Dalam hal ini, surplus penjual (SS) dihitung dengan cara harga tawaran - nilai unit penjual; (4) Total Surplus Pembeli (TSB), merupakan total dari kelebihan penerimaan untuk pembeli, yang di sebelah bawah dibatasi oleh Contract Price dan disebelah atas dibatasi oleh kurva permintaan. Dalam hal ini, surplus pembeli (SB) dihitung dengan cara nilai unit pembeli - harga pembelian; (5) Efisien pasar (Ef) menunjukkan seberapa besar profit yang dapat diserap oleh pembeli maupun penjual selama proses tarnsaksi dari total maksimum yang mungkin dihitung dengan rumus:

$\mathrm{Ef}=\{(\mathrm{TSS}+\mathrm{TSB}) / \mathrm{PM}\} * 100 \%$

Di mana TSS $=$ Total Surplus Penjual; TSB=Total Surplus Pembeli;

$\mathrm{PM}=$ Profit Maksimum

\section{Kendala di dalam Pelaksanaan Percobaan}

Dalam pelaksanaan percobaan ditemukan kendala, antara lain mencari personal untuk dijadikan pelaku percobaan; personal pelaku percobaan harus yang sudah mengerti tentang jenis-jenis pasar; jika personal sudah menjadi pelaku percobaan satu pasar, maka tidak dapat menjadi pelaku percobaan pasar yang lain karena akan menghasilkan data yang bias; menentukan insentif untuk pelaku percobaan; pelaku percobaan tidak seluruhnya mengerti apa yang diintruksikan oleh peneliti sehingga pada saat dilakukan rekapitulasi berapa keuntungan yang diperoleh masing-masing pelaku percobaan, masih ada yang hasilnya salah; jumlah pelaku percobaan harus sesuai dengan kebutuhan tipe pasar yang diteliti; peneliti tidak seluruhnya memahami dengan baik tugasnya masing-masing; dan tenaga peneliti dalam pelaksanaan kurang.

\section{HASIL DAN PEMBAHASAN}

Hasil percobaan yang akan disajikan dalam makalah ini hanya untuk variable Contract Price dan jumlah transasksi.

Tabel 2 Beberapa Respon dari Pengaruh 4 kombinasi Sistem Transaksi Pasar

\begin{tabular}{lcccc} 
& \multicolumn{2}{c}{ Pasar Persaingan Sempurna } & \multicolumn{2}{c}{ Pasar Monopoli } \\
& 5 PENJUAL & 5 PEMBELI & 1 PENJUAL - 5 PEMBELI \\
\hline$H K T$ & $D T$ & $D A$ & $5 T$ & DA \\
Pe & 550 & 550 & 550 & 550 \\
$Q$ & 582.43 & 602.50 & 747.5 & 672.50 \\
$E F$ & $6-8$ & $6-9$ & $64.00 \%$ & 2 \\
$S K$ & $87.30 \%$ & $97.27 \%$ & $13.37 \%$ & $99.00 \%$ \\
$S P$ & $43.32 \%$ & $37.84 \%$ & $86.63 \%$ & $76.76 \%$ \\
$C V$ & $56.68 \%$ & $62.16 \%$ & $17.66 \%$ & $8.30 \%$ \\
\hline
\end{tabular}


HKT : Harga Keseimbangan Teoritis

Pe : Rataan Kontrak Price

Q : Harga Keseimbangan Empiris (rataan Contract Price)

EF : Rataan Efisiensi

SK : Rataan Surplus Pembeli

SP : Rataan Surplus Penjual

CV : Rataan Koefisien Keragam

Gambar 1 : Grafik Kurva Penawaran S dan Permintaan D Teoritis (kiri),dan Perkembangan Contract Price untuk Transaksi 'PPS-DT' dan 'PPS-DA' dengan 5 Penjual dan 5 Pembeli selama 5 Periode Percobaan

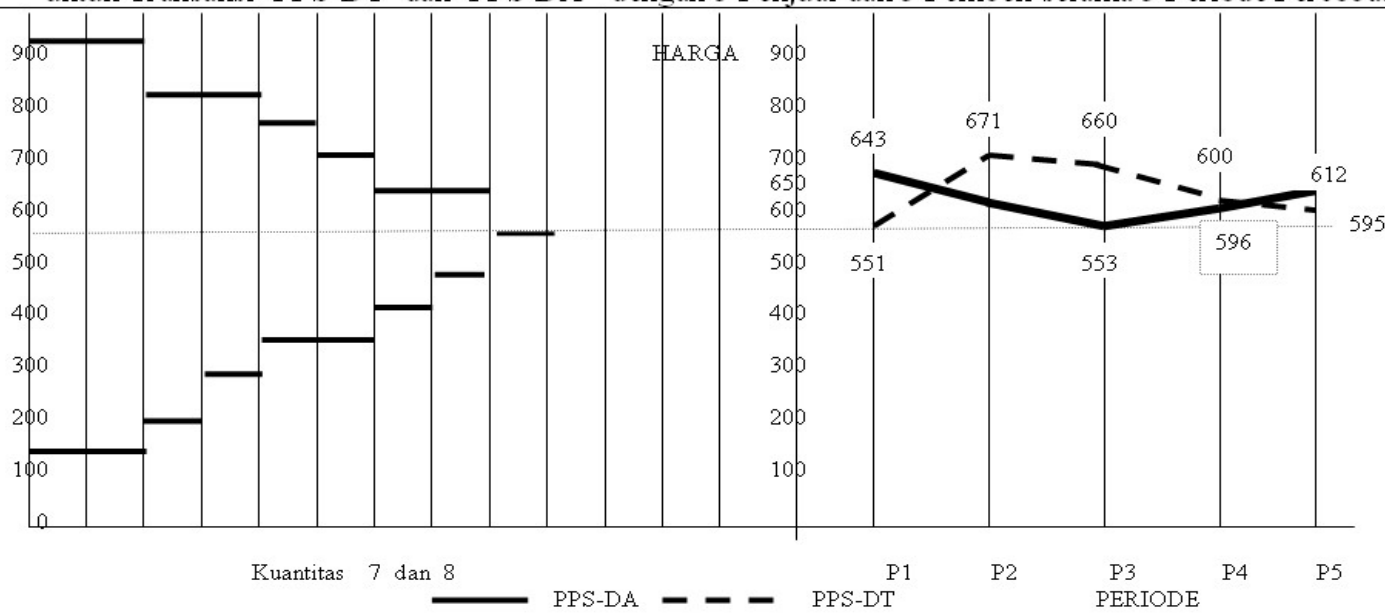

Gambar 2 : Grafik Kurva Penawaran (S) dan Permintaan (D) Teoritis (kiri),dan Perkembangan Contract Price untuk Transaksi MO-DT dan MO-DA dengan 1 Penjual dan 5 Pembeli selama 5 Periode Percobaan

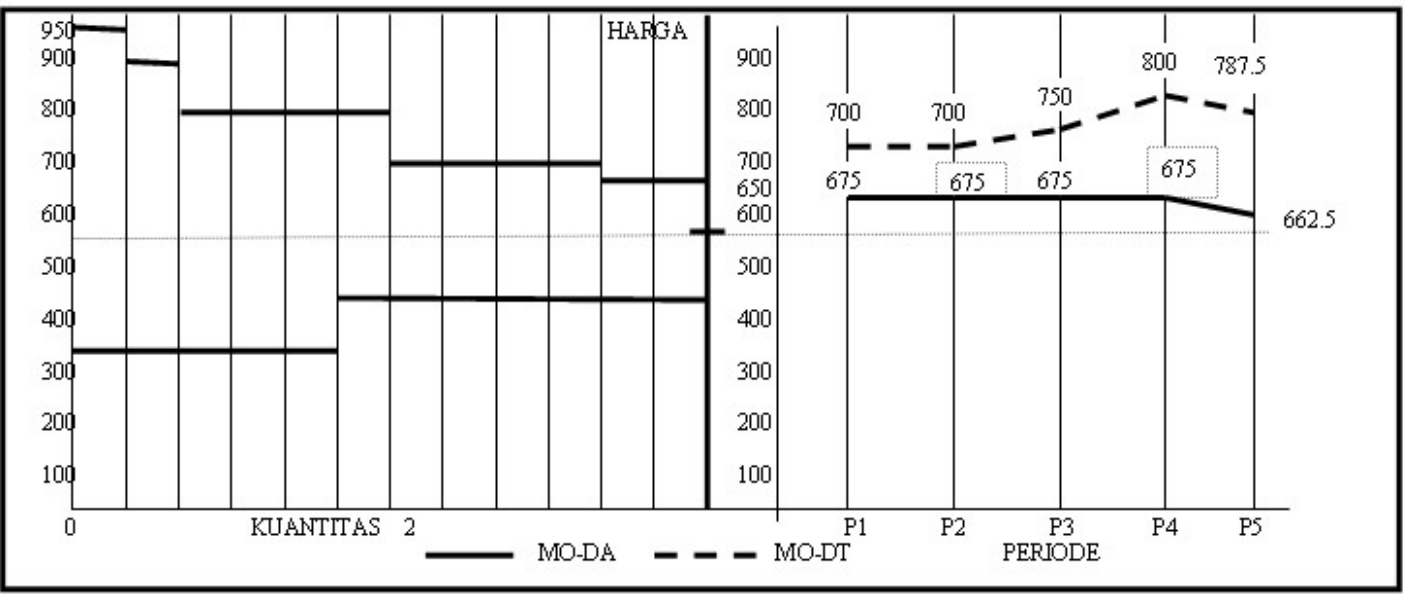

\section{Antara PPS-DT dan PPS-DA}

Pada Tabel 2, pada pasar pesaingan sempurna mempunyai rata-rata Contract Price selama 5 periode percobaan sebesar 582.5. Nilai ini lebih kecil dibandingkan dengan rata-rata Contract Price pada pasar persaingan Double Auction sebesar 602.50, di mana yang paling mendekati nilai prediksi pasar persaingan sempurna adalah percobaan pada pasar peresaingan sempurna dengan sistem 
transaksi disentralisasi. Sedangkan nilai keragaman yang paling kecil adalah pada pasar peesaingan dengan disentralisasi, tetapi tingkat efisiensi transaksi lebih efisien pada pasar peresaingan Double Auction dibandingkan dengan pasar persaingan sempurna dan disentralisasi. Jumlah yang terjual relatif sama antara kedua macam tipe transaksi di dalam pasar persaingan sempurna. Besarnya kelebihan keuntungan SP dan SK tampak PPS-DA lebih besar dibandingkan dengan PPS-DT.

Gambar 1 menyajikan pergerakan rataan Contract Price. Contract Price pasar persaingan sempurna dengan desentralisasi, nilai Contract Price pada periode pertama masih rendah karena dalam percobaan penjual masih berani melepas walaupun mendapatkan keuntungan yang kecil. Pada periode berikutnya, penjual ingin mendapatkan keuntungan yang lebih besar sehingga nilai Contract Price cenderung naik tajam, selanjutnya nilai cenderung menurun walapun masih di atas periode pertama. Sedangkan Contract Price pada PPS-DA periode pertama, nilai Contract Price bernilai tinggi karena penjual banyak alternatif atau pilihan menawarkan barangnya kepada pembeli lainnya, tetapi periode berikutnya nilai Contract Price menurun sampai pada priode tiga dan periode selanjutnya nilai Contract Price meningkat kembali.

\section{Antara MO-DT dan MO-DA}

Rata-rata Contract Price selama 5 periode menunjukkan bahwa rata-rata nilai Contract Price pasar monopoli dengan disentralisasi sebesar 747.5 lebih besar dari rata-rata nilai Contract Price pasar monopli, dengan nilai sebesar 672.5. Jumlah barang yang terjual sama dengan jumlah 2 unit antara kedua tipe transaksi dengan pasar monopoli. Tingkat efisiensi, besarnya surplus konsumen dan produsen pada tipe transaksi disentralisasi dalam pasar monopoli berturut-turut adalah 99\%, 23.76\%, dan 76.24\% lebih besar dibandingkan dengan tipe transaksi Double Auction di dalam pasar monopoli. Sedangkan tingkat keragaman nilai Contract Price tipe transaksi Double Auction dengan nilai 8.30\% lebih kecil dibandingkan dengan tipe transaksi disentralisasi pada pasar monopoli dengan nilai $17.66 \%$.

Pada Gambar 2, grafik pergerakan Contract Price tipe transaksi disentralisasi dan Double Auction pada pasar monopoli, terlihat bahwa tipe transaksi Double Auction pada pasar monopoli mempunyai kecenderungan bahwa nilai Contract Price mendatar dari periode-1 sampai pada periode5 , sedangkan tipe transaksi disentralisasi pada pasar monopoli pada permulaan periode-1 dan periode2 tidak ada perubahan mulai priode-3, selanjutnya menunjukkan kenaikan nilai Contract Price, dan pada akhir periode terjadi penurunan walaupun masih di atas periode- 2 .

Tabel 3 Analisis Variance dua faktor tipe Pasar (PPS dan MO) dengan tipe transaksi (DT dan DA)

\begin{tabular}{llrrrr}
\hline \multicolumn{1}{c}{ Source } & Df & \multicolumn{1}{c}{ SS } & MS & \multicolumn{1}{c}{ F } & Sig. \\
\hline Intercept & 1 & 699411.510 & 14.933 & 14.933 & .000 \\
Tipe Pasar & 1 & 50958.551 & 5954.632 & 5954.632 & .000 \\
Tipe Transaksi & 1 & 9701.132 & 34.680 & 34.880 & .020 \\
Tipe Pasar * Transaksi & 1 & 4790.132 & 6.640 & 6.640 & .089 \\
Error & 16 & 23375.180 & 3.279 & 3.279 & \\
\hline Total & 20 & 8788236.744 & & & \\
\hline
\end{tabular}

Hasil pengolahan Tabel 3 mengenai analisis variance dapat dijelaskan bahwa dapat perbedaaan yang nyata antara nilai Contract Price PPS (Pasar Persaingan Sempurna) dengan MO (Pasar Monopoli) dengan significant 0.00 di bawah 0.005. Begitu juga nilai Contract Price tipe transaksi, yaitu disentralisasi dengan Double Auction terdapat perbedaan yang significant pada tingkat 0.00 atas di bawah 0.005. Sedangkan interaksi antara tipe pasar dengan tipe transaksi tidak dapat perbedaan yang nyata pada tingkat significant .089 atau di atas 0.05 . 


\section{SIMPULAN}

Dari hasil penelitian, dapat disimpulkan bahwa (1) Rata-rata Contract Price (CP) selama 5 periode percobaan, terdapat bahwa nilai CP pada pasar persaingan sempurna lebih kecil dibandingkan dengann pasar monopoli; (2) Tingkat efisiensi antar tipe transaksi terlihat bahwa tipe transaksi Double Auction lebih efisien dibandingkan dengan tipe transaksi disentralisasi; (3) Terdapat perbedaan yang nyata nilai CP antara tipe transaksi, yaitu disentralisasi dengan Double Auction; (4) Terdapat perbedaan yang nyata nilai CP antara tipe pasar, yaitu pasar persaingan sempurna dengan pasar monopoli; (5) Jika percobaan ekonomi ini terus disempurnakan dan dikembangkan, maka tidak mustahil di masa mendatang akan memberikan kontribusi positif pembuktian teori-teori ekonomi dengan harga murah. Dengan demikian, percobaan ekonomi akan dapat memberikan sumbangan yang positif dalam peningkatan kesejahteraan manusia, sama dengan ilmu-ilmu eksperimental seperti kedokteran, pertanian, dan teknik yang sudah jelas memberikan manfaat banyak untuk kesejahteraan manusia. Dengan percobaan ekonomi, suatu saat kelak, ilmu ekonomi akan dapat mengantarkan manusia untuk pengambilan keputusan sebelum kegiatan tersebut dapat diterapkan pada keadaan yang sebenarnya. Peneliti memberikan saran berdasarkan temuan di lapangan sebagai berikut (1) Mencari personal yang benar-benar siap untuk dijadikan pelaku percobaan; (2) Personal pelaku percobaan harus yang sudah mengerti tentang percobaan ekonomi apa yang akan dilakukan; (3) Pelaku percobaan sebaiknya betul-betul memahami dan terlibat sehari-sehari, baik secara teori atau praktek tentang maksud percobaan dilakukan; (4) Diberikan imbalan yang jelas untuk pelaku percobaan; (5) Peneliti harus memahami dengan baik tugasnya masing-masing; dan (6) Tenaga peneliti dalam pelaksanaan cukup untuk melakukan percobaan.

\section{DAFTAR PUSTAKA}

Brandts, J., and Charles, A.H. (1999). An experimental test of equilibrium dominance in signaling games, forthcoming in American Economic Review.

Cadsby, C.B., Frank, M., and Maksimovic, V. (1992). equilibrium dominance in experimental financial markets, Working paper, University of Guelph.

Davis, D.D., and Holt, C.A. (1993). Experimental economics, New Jersey: Princeton University Press.

Douglas D.D. Antarctic atmospheric chemistry, Publisher Elsevier.

Douglas D.D., and Mitchell, S.K. (1997). Experimental economics: An introduction for applications to international trade, Ohio, Ohio State University: Publisher Dept. of Agricultural Economics.

Douglas D.D., and Holt, C.A. (1993). Experimental economics, United Kingdom: Princeton University Press Published.

Friedman, D., and Sunder, S. (1994). Experimental methods, New York: Cambridge University Press.

Hey, J.D. (1991). Experiments in economics, USA: Blakcwell Oxford UK \& Cambridge.

Kagel, J.H., and Roth, A.E. (1995). Introduction, di dalam “The Handbook Experimental Economics”, New Jersey: Princeton University Press. 
Juanda, B. (2000). Percobaan ekonomi untuk mengkaji pengaruh informasi serta jumlah penjual dan pembeli dalam transaksi pasar, Bogor: Fakultas MIPA Institut Pertanian Bogor.

Miller, R.M., and Charles R.P. (1985). Product quality signaling in experimental marklets.

Nelson, P. (1990). Information and consumer behavior. Journal of Political Economy.

Spence, A.M. (1984). Market signaling: Informational transfer in hiring and related screening process, Cambridge: Harvard University Press. 